Article

\title{
Impact of Nonchemical Protection of Broad Bean on Epigeic and Soil Arthropodofauna-Analysis in Field-Realistic Conditions
}

\author{
Janina Gospodarek * (D), Elżbieta Boligłowa and Katarzyna Gleń-Karolczyk \\ Department of Microbiology and Biomonitoring, University of Agriculture in Kraków, Al. Mickiewicza 21, \\ 31-120 Kraków, Poland; rrboligl@cyf-kr.edu.pl (E.B.); rrglen@cyf-kr.edu.pl (K.G.-K.) \\ * Correspondence: rrjgospo@cyf-kr.edu.pl
}

Received: 29 November 2019; Accepted: 21 January 2020; Published: 2 February 2020

\begin{abstract}
Plant protection methods, even those considered as safe for the environment and consumers, may have unexpected effects on nontarget organisms. The effect of broad bean protection, using Pythium oligandrum, paraffin-coated garlic pulp, and extract from grapefruit seeds and pulp on the abundance of epigeic and soil arthropodofauna in a 3-year field experiment was estimated. The effect was compared with chemical protection, which served as the reference to the conventional system. Use of nonchemical products did not affect the overall abundance of the studied arthropods such as Arachnida (except Acarina), Carabidae, Staphylinidae, and Collembola. These methods, however, may favor Formicidae. In comparison to chemicals (carboxin, mancozeb, deltamethrin, and alpha-cypermethrin), nonchemical preparations seemed to be safer for soil mites-they limited their abundance to a lesser degree. Some individual carabid species showed differing responses to the applied protection methods: Amara aenea occurred only in nonchemically protected areas, Platynus assimilis tends to prefer broad beans protected solely with P. oligandrum, while Anchomenus dorsalis prefer plots protected chemically (seed treatment and 3-time spraying). This may be the effect of the different shading of the soil surface as a result of the influence of protection measures on plant growth. Other explanations may include different vulnerability of species to preparations as well as indirect reaction to the occurrence of other taxa (reduced competition and impairment of food sources) or hormesis.
\end{abstract}

Keywords: biological preparations; nontarget organisms; organic farming; biopesticides

\section{Introduction}

The use of nonchemical preparations, e.g., based on plant extracts, is recently indicated as an important element in pest-management strategies in both organic and integrated farming [1-3]. These methods are considered environmentally safe and with low toxicity to nontarget organisms, including humans [4]. However, as demonstrated by similar nonchemical methods of protection, such measures may directly or indirectly (while affecting the cultivated plant) modify the occurrence of nontarget organisms, which include representatives of epigeic and soil arthropodofauna [5-7]. Many of these are the natural enemies of pests (Carabidae, Staphylinidae, and Arachnida) as well as important organisms involved in the decomposition of organic matter (e.g., soil Acarina and Collembola). In organic farming, where the use of natural agents is recommended, pest control depends for the most part on the natural enemies of pests, while soil arthropods are responsible for its biological activity and therefore for the high quality of the soil. Applying plant protection products may alter the living conditions of these organisms [8]. It is therefore essential to study the effect of these types of protection measures on the occurrence of soil and epigeic arthropods. 
Garlic pulp (preparation Bioczos BR, current name Kostki Himal z czosnkiem) is a germicidal, fungicidal and insecticidal product. In broad bean cultivation, its task is to prevent incursions of black bean aphid (Aphis fabae Scopoli), but it is also used with the purpose of deterring gnawing pests, such as pea weevils (Sitona spp.) and broad bean seed beetle (Bruchus rufimanus Boheman). Results indicate that its efficiency is comparable to [9] or lower $[10,11]$ than that of conventional products. In the latest literature, we can also find results indicating the high level of effectiveness of garlic bulb or straw extracts in the control of Tetranychus urticae Koch or T. viennensis Zacher [12-14]. Pythium oligandrum (preparation Polyversum WP) is intended for the protection of the root zone against fungal diseases as well as stimulation of plant growth, while extract from grapefruit (preparation Biosept $33 \mathrm{SL}$, current name Biosept Active) is a fungicide strengthening the plant protection system against pathogenic fungi.

Available publications lack information on the effect of preparation based on garlic, grapefruit, or those containing fungi parasites towards pathogenic fungi on epigeic or soil arthropods. However, there is evidence that some extracts prepared from other plants could affect nontarget soil organisms such as earthworms [15] or bacterial communities [16]. The few studies pertaining to the effects of chemical fungicides on these fauna also indicate the possibility of the adverse effects of those substances [17]. At the same time, the authors of the latest research on the effectiveness of plant extracts in pest control emphasize the need to analyze the impact of these preparations on the natural enemies of pests $[12,18]$. Thus, testing the effect of nonchemical protection on beneficial organisms in field-realistic conditions is of particular importance.

In the literature, there is a lot of information about the influence of chemical plant protection products on soil and epigeic invertebrates. Most of this (but not all) clearly indicates their negative impact on nontarget organisms, with the strength of this influence dependent on the number of applications, type of preparations, and taxonomic position of the arthropod [19-21]. However, there are also examples of chemicals that may favor some groups of arthropods [22-24]. Therefore, it is worth comparing two types of protection (biological and chemical) as well as various numbers of applications (protection intensity) of both groups of preparations.

The aim of this study was to determine the effect on the abundance of selected epigeic and soil arthropods exerted by nonchemical protection of broad bean (Vicia faba L.) cultivar Hangdown White against diseases and pests, using garlic pulp, grapefruit extract, and P. oligandrum. The observed effect was compared with protection with the use of chemical agents, namely fungicides-carboxin and mancozeb, as well as insecticides-deltamethrin, and alpha-cypermethrin. Our goal was first of all to check for general tendencies which could identify invertebrates particularly affected by the above substances and to thus identify those that will require, in the future, a more thorough analysis. In the case of representatives of Carabidae, we performed more detailed identification given their role in pest control. To achieve the assumed goal, we tried to discover (a) whether nonchemical protection products affected the abundance of soil and epigeic arthropodofauna in total and main groups of these organisms; (b) whether there was any significant difference between biological and chemical treatments in their influence on the studied arthropods; and (c) whether there was any specific response of particular species from Carabidae family to the investigated factors.

\section{Materials and Methods}

\subsection{The Location and Design of the Experiment}

The study was conducted in 2010-2012 at the Agricultural Experimental Farm of the University of Agriculture in Kraków, situated in Prusy $\left(50^{\circ} 07^{\prime} \mathrm{N}, 20^{\circ} 05^{\prime} \mathrm{E}\right)$, Poland. The soil on the site of the experiment is degraded chernozem, and formed from loess, with a granulometric composition of silt loam. The soil showed a reaction close to neutral ( $\mathrm{pH}$ in $\left.\mathrm{H}_{2} \mathrm{O}=6.56\right)$ and $2.28 \%$ organic matter content. The trial area was divided into three blocks: untreated, which served as a control $(14 \mathrm{~m} \times 14 \mathrm{~m}$, signed as UT); biologically protected ( $30 \mathrm{~m} \times 30 \mathrm{~m}$; treatments B1, B2, B3, and B4); and chemically protected ( $30 \mathrm{~m} \times 22 \mathrm{~m}$; treatments $\mathrm{Ch} 1, \mathrm{Ch} 2$, and Ch3). In the biologically protected block, Polyversum 
WP (Biopreparaty Sp. z o.o., $10^{6}$ Pythium oligandrum oospores per $1 \mathrm{~g}$ of product, fungicide, and growth stimulator), Bioczos BR (Himal PPH, paraffin-coated garlic pulp with germicidal, fungicidal, and insecticidal activity), and Biosept 33 SL (Biosept sp. z o. o. Sp. K., extract from grapefruit seeds and pulp-33\%, fungicide) preparations were used. In the chemically protected block, the following were used: fungicides: Vitavax 200 FS (Arysta LifeScience Netherlands B.V., Amsterdam, carboxin/5,6-dihydro-2-methyl-N-phenyl-1,4-oxathiin-3-carboxamide (a compound from the carboxylic anilides group) - $200 \mathrm{~g}$ per litre of preparation — and thiuram/tetramethylthiuram disulfide (a compound from the dithiocarbamates group)—200 g per litre of preparation) and Penncozeb $80 \mathrm{WP}$ (UPL Europe Ltd., Warrington, England, mancozeb (a compound from the dithiocarbamates group) $-80 \%$ $\left(800 \mathrm{~g} \mathrm{~kg}^{-1}\right)$ ); insecticides: Decis 2.5 EC (Bayer SAS, Lyon, France, deltamethrine (a compound from the pyrethroids group) $-25 \mathrm{~g}$ per litre of preparation (2.8\%)) and Fastac 100 EC (BASF SE, Ludwigshafen, Germany, alpha-cypermethrin (a compound from the pyrethroids group)-100 g per litre of preparation $(10.87 \%))$. Chemical protection served in our research as a reference to conventional plant protection. Each of the three blocks was further divided into experimental plots $(6 \mathrm{~m} \times 6 \mathrm{~m})$ according to the specific protection method (Table 1). This design provided eight combinations of plant protection in four replications ( 32 plots in total). The position of the plots was randomised within blocks. The blocks were separated by $8-\mathrm{m}$ wide strips of oat except for the chemically protected block, which was located $50 \mathrm{~m}$ away from other blocks and separated by oat to avoid the effects of pesticide drift. Similar buffer zones with cereals (1.25-m wide stripes) due to their neutrality for pests had been used by other authors in previous studies on the effect of crop coordinates on natural enemies of pests [25]. The 2-m wide space between the experimental plots was maintained mechanically as bare soil. The experiment was carried out using the Hangdown White cultivar of broad bean. Cereal plants (oat in 2009, winter wheat in 2010, and spring barley in 2011) were used each year as a forecrop for broad bean. During the vegetation period, broad bean was protected according to the scheme presented in Table 1. Plant protection variants from UT to B4 fulfilled the requirements of organic farming in broad bean cultivation. These blocks were located within a larger area which had since 2007 been converted to organic status. On the sites protected with synthetic pesticides, soil tillage and fertilisation were conducted in compliance with current agrotechnical recommendations for this plant species. Mineral fertilisation (NPK) in this part of the experiment was adjusted to match the abundance of these components in the soil and to broad bean nutritional requirements. Each year, the blocks were located in different parts of the larger fields (organic for UT + all biological treatments and conventional for Ch treatments). The plots within the blocks were randomized anew each year. Broad bean seeds were sown in the first days of April (7 April 2010, 1 April 2011, and 10 April 2012) with a row spacing of $50 \mathrm{~cm}$ and seed spacing of $10 \mathrm{~cm}$ per row at a depth of $6 \mathrm{~cm}$. Weed control was maintained throughout the experiment using mechanical methods. Broad bean seed were manually dressed with the use of Polyversum WP and Vitawax 200 FS dressings. The spraying of plants was done with a hand sprayer (Titan 12 knapsack sprayer, Marolex).

Table 1. Scheme of protection of broad bean against pest and diseases.

\begin{tabular}{|c|c|c|c|}
\hline Treatments & Protection Method & Preparation, Dose & Date of Application \\
\hline UT & Untreated & Without protection & \\
\hline B1 & Seed treatment & $\begin{array}{l}\text { Polyversum WP, } \\
10 \mathrm{~g} / \mathrm{kg} \text { of seeds }\end{array}$ & before sowing \\
\hline \multirow{3}{*}{ B2 } & \multirow{3}{*}{$\begin{array}{l}\text { Seed treatment } \\
\text { and three-time } \\
\text { spraying }\end{array}$} & $\begin{array}{l}\text { Polyversum WP, } \\
10 \mathrm{~g} / \mathrm{kg} \text { of seeds }\end{array}$ & before sowing \\
\hline & & $\begin{array}{l}\text { Bioczos BR, } \\
4 \text { briquettes/L of water } \\
\text { (two times) }\end{array}$ & $\begin{array}{l}\text { when first aphids appear ( } 26 \text { May 2010; } 25 \text { May 2011; } \\
11 \text { May 2012) } \\
\text { by the end of flowering first inflorescences (15 June } \\
2010 ; 11 \text { June 2011; } 31 \text { May 2012) }\end{array}$ \\
\hline & & Biosept 33 SL, 2 L/ha & $\begin{array}{l}\text { before flowering (1 June 2010; } 29 \text { May 2011; } \\
18 \text { May 2012) }\end{array}$ \\
\hline
\end{tabular}


Table 1. Cont.

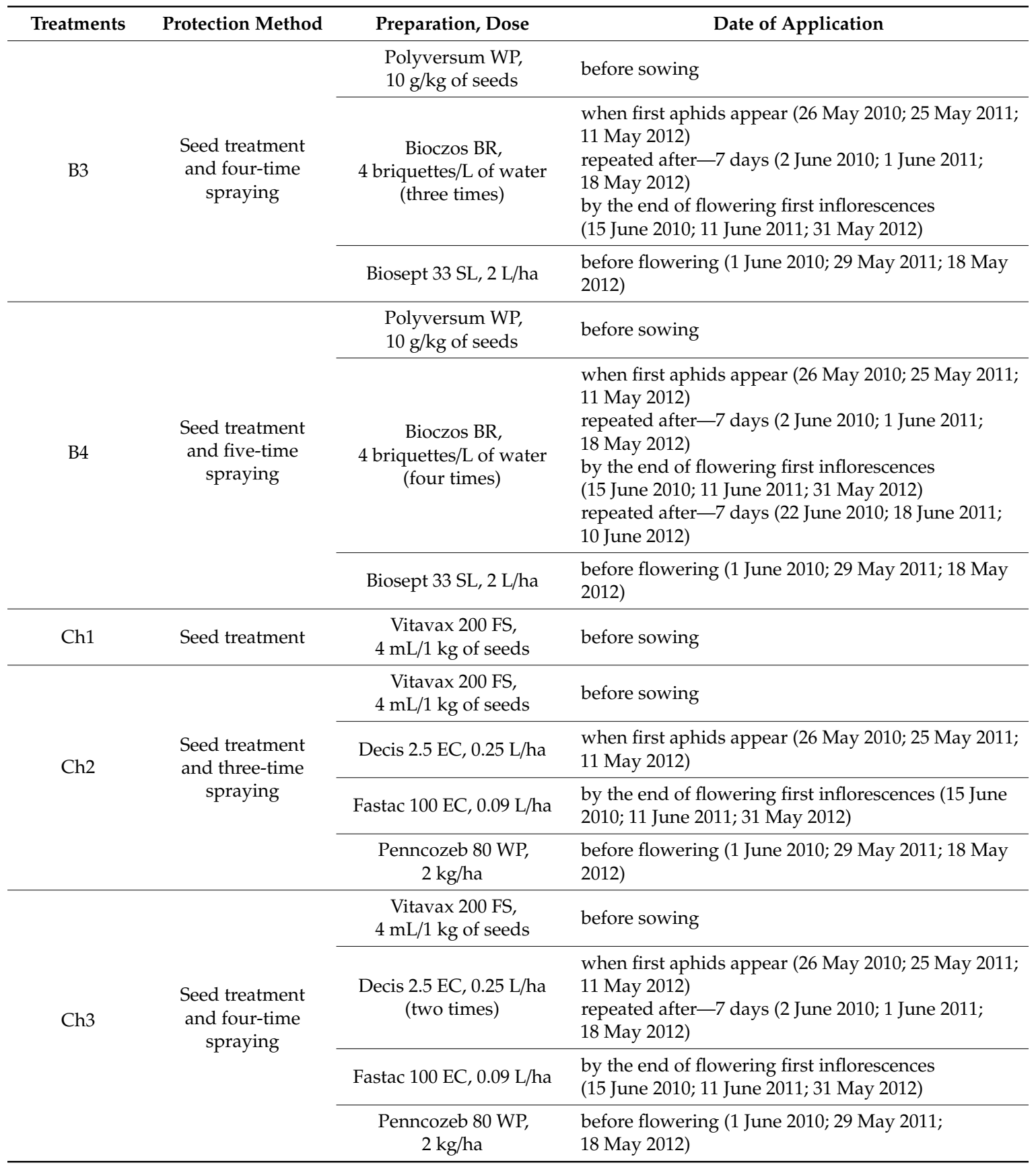

\subsection{Fauna Sampling}

One pitfall trap was placed in the central part of each plot in order to capture arthropodofauna. The distance between individual traps was $8 \mathrm{~m}$. Although pitfall traps are typically used for larger areas, this type of measuring gives a very good indication of epigeic invertebrate abundance [26], even in the case of small plots [5,6]. Hummel et al. [5] used pitfall traps $2.9 \mathrm{~m}$ apart on plots of $36 \mathrm{~m}^{2}$ surface (the same surface as in our research), while Hurej and Twardowski [6] used even smaller plots $\left(15 \mathrm{~m}^{2}\right)$ with $0.3-\mathrm{m}$ distances between plots and one trap in the central part of each plot. The trap was composed of a glass container (120 $\mathrm{mm}$ high, $70 \mathrm{~mm}$ in diameter) filled to $\frac{1}{4}$ with a preserving solution (ethylene glycol), sunk in the soil at ground level, and covered with a plastic green roof for protection against precipitation. The roof was held in a position, ca. $3-5 \mathrm{~cm}$ above the surface using $10-\mathrm{cm}$ plastic sticks. The traps were emptied once a week during the broad bean vegetation period 
(usually from the end of May until the end of July), and the retrieved arthropods were identified to the order, family, or species level using relevant keys. The dates of the start and the end of sampling were as follows: 21 June 2010 and 12 August 2010; 26 May 2011 and 18 July 2011; and 1 June 2012 and 2 August 2012. The delay in starting fauna sampling in 2010 was caused by heavy rains at the beginning of June, which destroyed some of the traps. Consequently, the results from the first sampling are not included. The overall abundance of fauna was analysed, with specific reference to carabid beetles (Coleoptera, Carabidae), rove beetles (Coleoptera, Staphylinidae), arachnids (Arachnida, including Araneae, Opiliones, and Acarina), and springtails (Collembola). We also included in the analysis the abundance of ants (Formicidae) because of the role they play in the plant-aphid-natural enemy system. Predatory carabid beetles, given their role in pest control, were identified to the species level [27]. Although the most common method for assessing Collembola and Acarina (which are representatives of soil fauna rather than being epigeic) abundance is analysis of soil samples, pitfall traps are also mentioned as one of the method of catching these organisms [28]. As calculated by Querner and Bruckner [28], pitfall trapping is a method which demands much lower work effort, and the number of identified Collembola species is only slightly lower than for soil samples (an average thirteen and seventeen, respectively, per site).

\subsection{Selected Morphological Parameters of Broad Bean}

Given that, according to the literature, one of the more important factors affecting the occurrence of epigeic and soil arthropodofauna is the degree of soil shading [5,29-32], selected morphological parameters of broad been plants, i.e., the height of plants and the number of branching were determined. The analysis was performed each year at the milk-ripe stage of broad bean seeds (usually at the end of June) in 20 randomly selected plants from each plot. This is the moment of broad bean maximum size, and at this moment, we could clearly see differences between plants protected in different ways. We chose these two parameters to help the interpretation of obtained results.

\subsection{Statistical Analysis of the Data}

Statistical analysis was conducted using Statistica 13.1 PL software. The obtained results were checked for normality (Shapiro-Wilk test with Lilliefors correction) and equality of variance (Levene's test), and when necessary, the data were log transformed. One- and two-factor analyses of variance were performed, and the means were differentiated using Fisher's LSD test at $p<0.05$. The Shannon-Wiener diversity index $\left(\mathrm{H}^{\prime}\right)$ [33] was calculated for predatory carabid beetles, given their role in pest control. This index is commonly used in the analysis of the species composition of fauna caught using pitfall traps [34]. We used this index in our study to assess whether the different methods of protection affected the number of individuals of particular species in relation to the total number of trapped Carabidae.

\section{Results}

\subsection{The Trapping Dynamics of Studied Arthropods}

The trapping dynamics of the analysed arthropodofauna in the 2010 season indicated its peak activity around mid-July. The 2011 season was similar in this respect, although an elevated number of trapped individuals was also noted in the second half of June. In 2012, the largest abundance of arthropods were captured in mid-June (Table 2). In most cases, the dynamics of fauna abundance were similar in sites subjected to different protection measures. The largest number of individuals was recorded in 2011. This was significantly more than in 2010 and 2012, which suggests the strong influence of weather conditions on these organisms. The 2011 research season featured moderate total precipitation ( $377.4 \mathrm{~mm}$ in the April-July period) and average daily temperatures close to the long-term average temperature (1977-2007), whereas 2010 was a substantially more humid year $(582.30 \mathrm{~mm}$ precipitation) and 2012 was dryer (299.30 mm) (Figure 1). 
Table 2. Trapping dynamics of investigated arthropodofauna (means of individuals/trap) in broad bean crop: Treatments are the same as in Table 1 . Values after \pm symbol denote standard errors.

\begin{tabular}{|c|c|c|c|c|c|c|c|c|}
\hline Date & UT & B1 & B2 & B3 & B4 & Ch1 & Ch2 & Ch3 \\
\hline 21 June 2010 & $58 \pm 24$ & $39 \pm 7$ & $56 \pm 3$ & $38 \pm 14$ & $39 \pm 6$ & $27 \pm 14$ & $27 \pm 10$ & $39 \pm 3$ \\
\hline 25 June 2010 & $30 \pm 3$ & $49 \pm 10$ & $30 \pm 6$ & $42 \pm 7$ & $27 \pm 18$ & $11 \pm 5$ & $32 \pm 11$ & $38 \pm 14$ \\
\hline 1 July 2010 & $51 \pm 7$ & $74 \pm 40$ & $48 \pm 26$ & $49 \pm 13$ & $41 \pm 5$ & $44 \pm 10$ & $67 \pm 14$ & $52 \pm 9$ \\
\hline 8 July 2010 & $56 \pm 5$ & $45 \pm 5$ & $56 \pm 4$ & $60 \pm 6$ & $62 \pm 11$ & $58 \pm 4$ & $68 \pm 20$ & $70 \pm 7$ \\
\hline 15 July 2010 & $98 \pm 29$ & $176 \pm 133$ & $56 \pm 4$ & $103 \pm 42$ & $87 \pm 14$ & $66 \pm 13$ & $144 \pm 90$ & $118 \pm 27$ \\
\hline 22 July 2010 & $50 \pm 14$ & $66 \pm 8$ & $25 \pm 6$ & $25 \pm 8$ & $42 \pm 4$ & $48 \pm 3$ & $34 \pm 11$ & $39 \pm 12$ \\
\hline 29 July 2010 & $29 \pm 7$ & $42 \pm 19$ & $35 \pm 11$ & $36 \pm 5$ & $37 \pm 8$ & $28 \pm 3$ & $23 \pm 4$ & $31 \pm 6$ \\
\hline 4 August 2010 & $49 \pm 10$ & $66 \pm 14$ & $29 \pm 2$ & $24 \pm 5$ & $33 \pm 5$ & $29 \pm 4$ & $32 \pm 7$ & $29 \pm 4$ \\
\hline 12 August 2010 & $29 \pm 5$ & $36 \pm 7$ & $13 \pm 5$ & $30 \pm 5$ & $29 \pm 18$ & $40 \pm 4$ & $50 \pm 16$ & $29 \pm 7$ \\
\hline 26 May 2011 & $33 \pm 7$ & $59 \pm 18$ & $43 \pm 16$ & $49 \pm 19$ & $41 \pm 7$ & $59 \pm 9$ & $44 \pm 13$ & $51 \pm 14$ \\
\hline 3 June 2011 & $29 \pm 3$ & $24 \pm 3$ & $34 \pm 11$ & $35 \pm 10$ & $28 \pm 3$ & $46 \pm 8$ & $40 \pm 4$ & $38 \pm 8$ \\
\hline 11 June 2011 & $33 \pm 3$ & $39 \pm 5$ & $34 \pm 11$ & $37 \pm 13$ & $31 \pm 5$ & $51 \pm 8$ & $42 \pm 2$ & $51 \pm 3$ \\
\hline 18 June 2011 & $89 \pm 7$ & $96 \pm 25$ & $80 \pm 20$ & $80 \pm 36$ & $89 \pm 12$ & $143 \pm 26$ & $66 \pm 18$ & $78 \pm 8$ \\
\hline 25 June 2011 & $44 \pm 17$ & $71 \pm 17$ & $85 \pm 26$ & $53 \pm 33$ & $50 \pm 5$ & $57 \pm 14$ & $54 \pm 7$ & $82 \pm 11$ \\
\hline 2 July 2011 & $42 \pm 6$ & $57 \pm 8$ & $77 \pm 39$ & $44 \pm 6$ & $27 \pm 16$ & $41 \pm 18$ & $16 \pm 15$ & $28 \pm 18$ \\
\hline 9 July 2011 & $43 \pm 5$ & $72 \pm 21$ & $52 \pm 9$ & $44 \pm 9$ & $48 \pm 10$ & $55 \pm 14$ & $80 \pm 23$ & $115 \pm 2$ \\
\hline 18 July 2011 & $99 \pm 13$ & $85 \pm 5$ & $133 \pm 10$ & $67 \pm 10$ & $92 \pm 9$ & $88 \pm 12$ & $99 \pm 4$ & $104 \pm 5$ \\
\hline 1 June 2012 & $85 \pm 4$ & $54 \pm 3$ & $57 \pm 23$ & $65 \pm 11$ & $28 \pm 6$ & $81 \pm 23$ & $55 \pm 23$ & $60 \pm 7$ \\
\hline 6 June 2012 & $42 \pm 7$ & $46 \pm 1$ & $24 \pm 7$ & $22 \pm 3$ & $25 \pm 4$ & $58 \pm 7$ & $21 \pm 4$ & $18 \pm 7$ \\
\hline 15 June 2012 & $81 \pm 19$ & $60 \pm 13$ & $72 \pm 36$ & $73 \pm 15$ & $105 \pm 14$ & $125 \pm 67$ & $58 \pm 27$ & $53 \pm 8$ \\
\hline 22 June 2012 & $47 \pm 10$ & $51 \pm 24$ & $57 \pm 9$ & $58 \pm 21$ & $46 \pm 13$ & $61 \pm 10$ & $92 \pm 30$ & $82 \pm 12$ \\
\hline 29 June 2012 & $21 \pm 13$ & $18 \pm 5$ & $12 \pm 3$ & $16 \pm 2$ & $17 \pm 2$ & $15 \pm 7$ & $29 \pm 17$ & $23 \pm 4$ \\
\hline 7 July 2012 & $24 \pm 5$ & $30 \pm 3$ & $23 \pm 5$ & $17 \pm 5$ & $18 \pm 3$ & $27 \pm 14$ & $37 \pm 1$ & $39 \pm 10$ \\
\hline 17 July 2012 & $50 \pm 17$ & $38 \pm 14$ & $46 \pm 7$ & $28 \pm 3$ & $37 \pm 11$ & $27 \pm 8$ & $44 \pm 7$ & $32 \pm 10$ \\
\hline 2 August 2012 & $78 \pm 14$ & $70 \pm 7$ & $73 \pm 5$ & $68 \pm 27$ & $62 \pm 15$ & $62 \pm 4$ & $77 \pm 2$ & $70 \pm 10$ \\
\hline
\end{tabular}

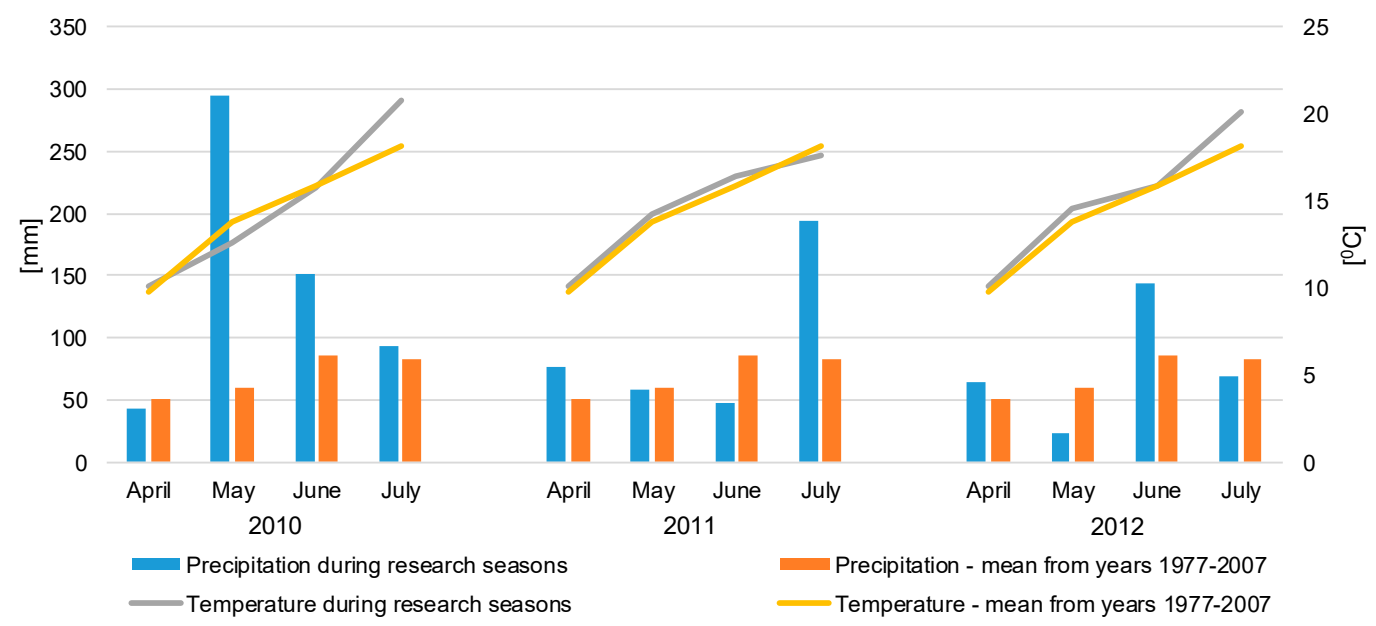

Figure 1. Monthly sum of precipitation and average daily temperature during the study period.

\subsection{The Influence of the Protection Method and the Interaction of the Year of Study and Protection Method}

Statistical analysis of data from 3 years of research showed a significant influence of the year of study on the overall abundance of caught fauna (Figure 2a, Table 3). The protection method used in broad bean cultivation as well as interaction of the year and the protection method had no significant influence.

One of the most important groups of captured arthropods were arachnids (Arachnida). They were trapped in their largest number in the 2010 season (Figure 2b). During that research season, the lowest abundance of these invertebrates was noted in the site subjected to chemical protection with a maximum number of treatments (site $\mathrm{Ch} 3$ ). The difference in the number of individuals was statistically proven in relation to the untreated site and all nonchemical protection methods. The situation was contrary to that of the 2011 season, when arachnids were captured in the largest number in the site subjected to the maximum chemical protection - their number was approximately 2.5 times larger than that found 
in the untreated site. The difference in the number of individuals was also statistically significant with regard to the B4 treatment. In 2012, the protection method used had no significant effect on the abundance of arachnids. Analysis of data from three seasons showed a significant influence of the year of study and the interaction of the year and protection method on the analysed parameter. Protection method alone did not influence the abundance of arachnids (Table 3).

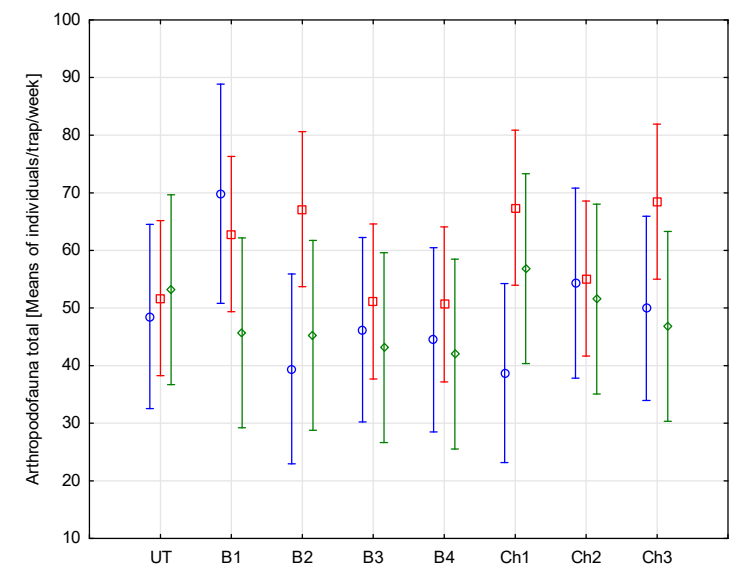

(a)

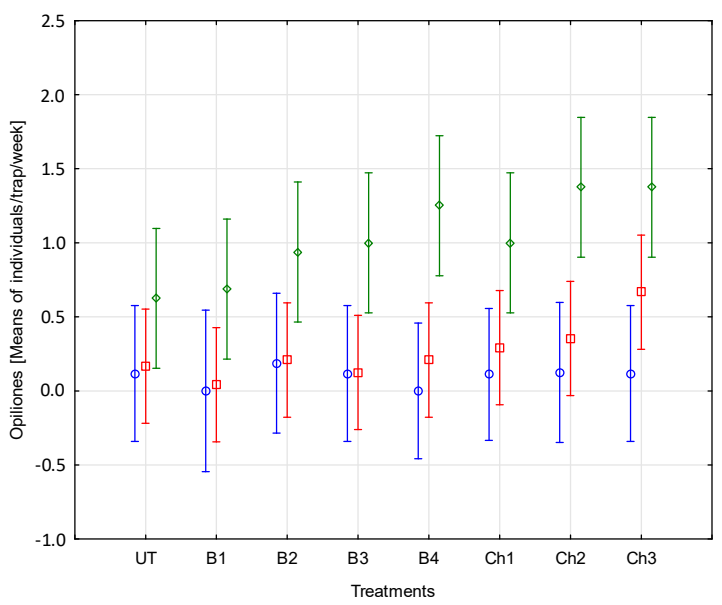

(c)

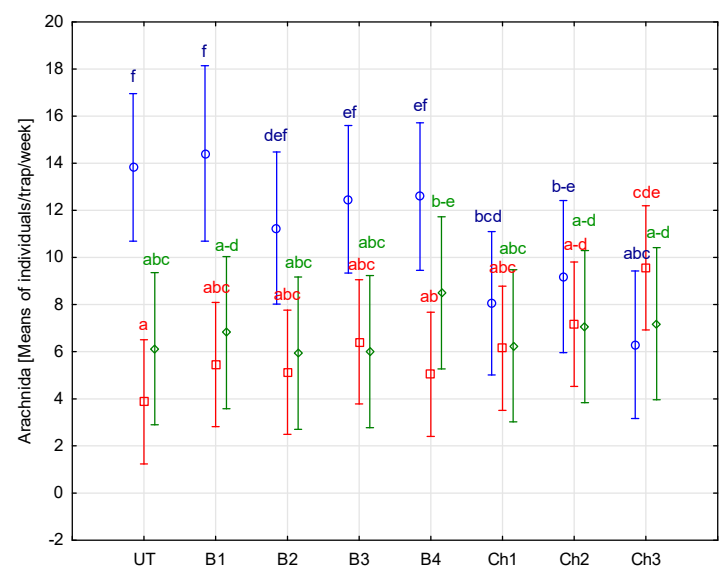

(b)

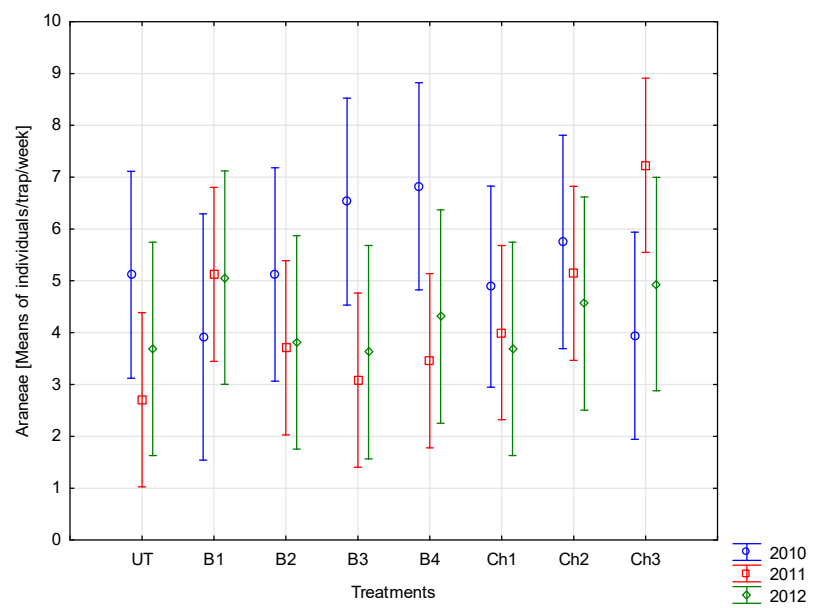

(d)

Figure 2. Number of trapped individuals of (a) arthropodofauna total, (b) Arachnida total, (c) Opiliones and (d) Araneae in broad bean crop depending on the protection method used: Treatments are the same as in Table 1. Vertical bars denote 0.95 confidence intervals. Means followed by the same letters are not significantly different according to the LSD test $(p<0.05)$, factors: year $\times$ protection method.

Harvestmen (Opiliones) were captured in the largest number in the 2012 season (Figure 2c). The analysis of data showed a significant effect only in the case of the year of study (Table 3), while spiders (Araneae) did not respond significantly to any of the studied factors (Figure 2d, Table 3).

From the viewpoint of plant protection against pests, beetles from the carabid beetle family (Carabidae) represent an important group living among the soil surface arthropods. Individuals from this family occurred in larger numbers in the 2010 season than in the 2011 and 2012 seasons (Figure 3a). The statistical analysis has shown that this was only the year of study that had a significant effect (Table 3). No significant effect of the method of protection or of the interaction of the two aforementioned factors was found on the total numbers of Carabidae trapped. In the 2010 season, the highest abundance of these beetles was recorded at the site protected with fungicide dressing (carboxin) and with one fungicidal (mancozeb) and two insecticidal (deltamethrin and alpha-cypermethrin) sprayings (site Ch2). In the 2011 season, carabid beetles were captured in their largest number at the site receiving the maximum number of treatments with chemical products (site Ch3). However, the situation was 
different in the 2012 season, when Carabidae were trapped most abundantly in the site protected solely by P. oligandrum.

Table 3. Results of the statistical analysis of the presence of investigated arthropodofauna total and selected groups of invertebrates. SS-sum of squares, $d f$-degrees of freedom, MS-mean squares, F-Fisher-Snedecor's test, $p$-probability level.

\begin{tabular}{|c|c|c|c|c|c|}
\hline Effects & SS & $d f$ & MS & $F$ & $p$ \\
\hline & \multicolumn{5}{|c|}{ Arthropodofauna Total } \\
\hline Year & $12,867.240$ & 2 & 6433.620 & 5.722 & 0.004 \\
\hline Protection method & 7448.318 & 7 & 1064.045 & 0.946 & 0.470 \\
\hline \multirow[t]{2}{*}{ Year $\times$ protection method } & $15,608.999$ & 14 & 1114.929 & 0.992 & 0.461 \\
\hline & \multicolumn{5}{|c|}{ Arachnida total } \\
\hline Year & 2016.750 & 2 & 1008.375 & 23.345 & 0.000 \\
\hline Protection method & 172.894 & 7 & 24.699 & 0.572 & 0.779 \\
\hline \multirow[t]{2}{*}{ Year $\times$ protection method } & 1396.790 & 14 & 99.771 & 2.310 & 0.004 \\
\hline & \multicolumn{5}{|c|}{ Opiliones } \\
\hline Year & 66.173 & 2 & 33.086 & 35.796 & 0.000 \\
\hline Protection method & 8.851 & 7 & 1.264 & 1.368 & 0.217 \\
\hline \multirow[t]{2}{*}{ Year $\times$ protection method } & 6.134 & 14 & 0.438 & 0.474 & 0.946 \\
\hline & \multicolumn{5}{|c|}{ Araneae } \\
\hline Year & 90.933 & 2 & 45.467 & 2.593 & 0.076 \\
\hline Protection method & 104.881 & 7 & 14.983 & 0.854 & 0.543 \\
\hline \multirow[t]{2}{*}{ Year $\times$ protection method } & 374.796 & 14 & 26.771 & 1.527 & 0.098 \\
\hline & \multicolumn{5}{|c|}{ Formicidae } \\
\hline Year & 1658.028 & 2 & 829.014 & 44.321 & 0.000 \\
\hline Protection method & 795.403 & 7 & 113.629 & 6.075 & 0.000 \\
\hline \multirow[t]{2}{*}{ Year $\times$ protection method } & 637.585 & 14 & 45.542 & 2.435 & 0.003 \\
\hline & \multicolumn{5}{|c|}{ Carabidae } \\
\hline Year & 383.938 & 2 & 191.969 & 1.602 & 0.000 \\
\hline Protection method & 190.982 & 7 & 27.283 & 1.507 & 0.163 \\
\hline \multirow[t]{2}{*}{ Year $\times$ protection method } & 322.528 & 14 & 23.038 & 1.272 & 0.221 \\
\hline & \multicolumn{5}{|c|}{ Staphylinidae } \\
\hline Year & 1254.054 & 2 & 627.027 & 39.926 & 0.000 \\
\hline Protection method & 91.240 & 7 & 13.034 & 0.830 & 0.563 \\
\hline Year $\times$ protection method & 174.534 & 14 & 12.467 & 0.794 & 0.676 \\
\hline
\end{tabular}

The total carabid catch represents 39 species (Table S1). Only in the case of 3 species was a significant impact of the protection method or interaction of the protection method and the year of study found (Table 4). In other cases, either no significant impact of the factors studied was noted or differences in numbers were only due to the year of the study (Table S2). Amara aenea (De Geer) was caught only in nonchemically protected plots and in the untreated site (Figure 4a). For Platynus assimilis (Paykull), the most suitable was treatment with P. oligandrum only, while Anchomenus dorsalis (Pontoppidan) during two years of study preferred treatment Ch2 with moderate chemical protection (Figure 4b,c). The Shannon-Wiener diversity index showed slightly increased values in the case of biologically protected treatments compared to the untreated site (Table S1). The lowest value was obtained for the site protected with carboxin (fungicide) dressing (Ch1). 


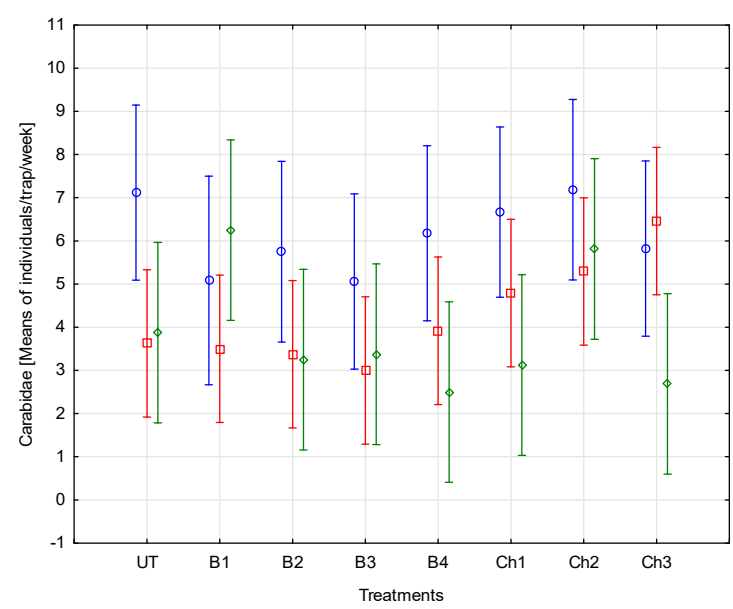

(a)

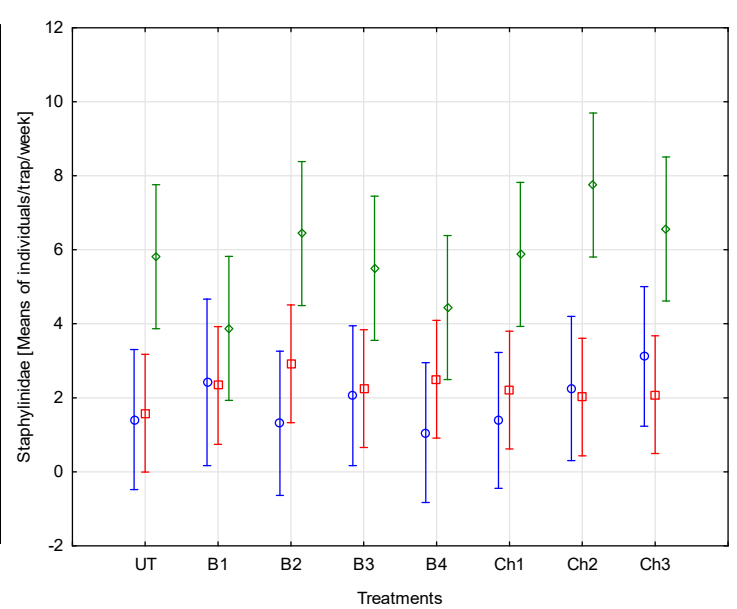

(b)

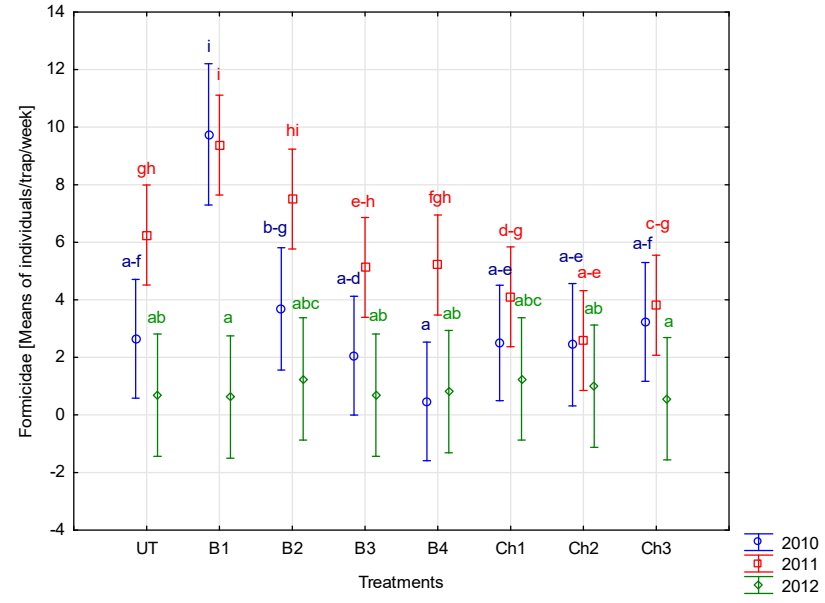

(c)

Figure 3. Number of trapped individuals of (a) Carabidae, (b) Staphylinidae, and (c) Formicidae in broad bean crop depending on the protection method used: Treatments are the same as in Table 1. Vertical bars denote 0.95 confidence intervals. Means followed by the same letters are not significantly different according to the LSD test $(p<0.05)$, factors: year $\times$ protection method.

Table 4. Results of the statistical analysis of the presence of selected Carabidae species (other results are presented in Table S2). SS—sum of squares, $d f$-degrees of freedom, MS-mean squares, F-Fisher-Snedecor's test, $p$ - probability level.

\begin{tabular}{lccccc}
\hline \multicolumn{1}{c}{ Effects } & SS & $d f$ & MS & $\boldsymbol{F}$ & $p$ \\
\hline \multicolumn{7}{c}{ Amara aenea } \\
\hline Year & 0.2416 & 2 & 0.121 & 4.856 & 0.008 \\
Protection method & 0.740 & 7 & 0.106 & 4.253 & 0.000 \\
Year $\times$ protection method & 0.326 & 14 & 0.023 & 0.936 & 0.520 \\
\hline & \multicolumn{5}{c}{ Platynus assimilis } \\
\hline Year & 1.808 & 2 & 0.904 & 13.057 & 0.000 \\
Protection method & 1.377 & 7 & 0.197 & 2.840 & 0.007 \\
Year $\times$ protection method & 2.776 & 14 & 0.198 & 2.863 & 0.000 \\
\hline & \multicolumn{7}{c}{ Anchomenus dorsalis } \\
\hline Year & 93.281 & 2 & 46.641 & 16.935 & 0.000 \\
Protection method & 77.326 & 7 & 11.047 & 4.011 & 0.000 \\
Year $\times$ protection method & 91.981 & 14 & 6.570 & 2.386 & 0.003 \\
\hline
\end{tabular}




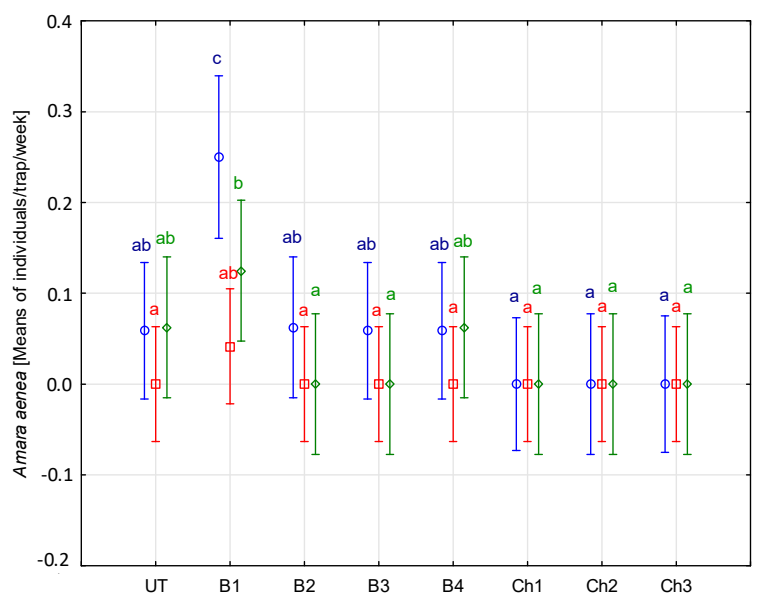

(a)

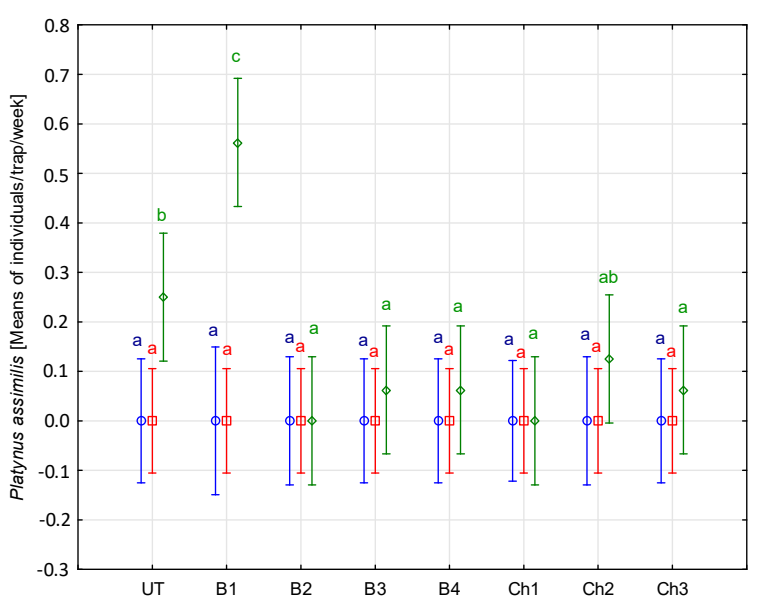

(b)

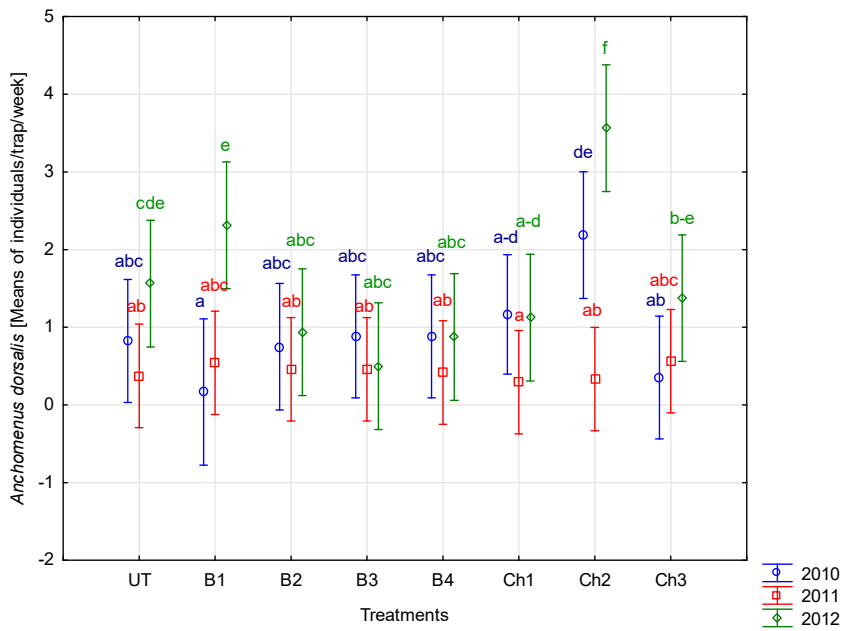

(c)

Figure 4. Number of trapped individuals of (a) Amara aenea, (b) Platynus assimilis, and (c) Anchomenus dorsalis in broad bean crop depending on the protection method used: Treatments are the same as in Table 1. Vertical bars denote 0.95 confidence intervals. Means followed by the same letters are not significantly different according to the LSD test $(p<0.05)$, factors: year $\times$ protection method.

Beetles from the rove beetle family (Staphylinidae) were captured less frequently than were Carabidae, the largest number being noted in 2012 (Figure 3b). The overall analysis of data from all years of research did not show any significant effect of any crop protection method on the abundance of this group of organisms in broad bean cultivation (Table 3). Only the year of study was a factor that significantly differentiated the number of individuals caught.

Ants (Formicidae) were affected both by the year of study and by protection method (Figure 3c, Table 3). Nonchemical methods (especially P. oligandrum - treatment B1) favored the occurrence of ants, particularly in the 2011 season, when they were caught most often, while in the same season, a significant reduction in the capture of Formicidae was noted in some chemical protection treatments (Ch2). Noteworthy was also the decrease in the number of these arthropods along with the increase in the use of garlic pulp (treatment B1-0 garlic pulp versus B3-garlic pulp three times or B4-garlic pulp four times).

The largest number of springtails (Collembola) was captured in the 2011 season (Figure 5a). They were trapped almost half as frequently as in the 2010 season. Only the year of study had a significant influence on their abundance (Table 5). 


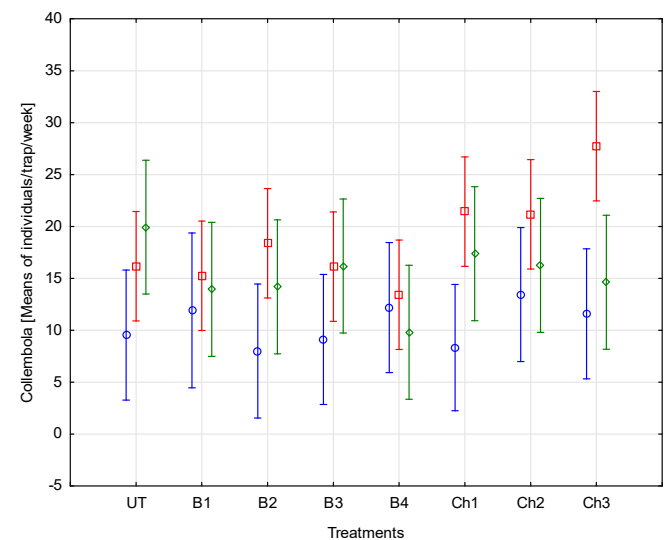

(a)

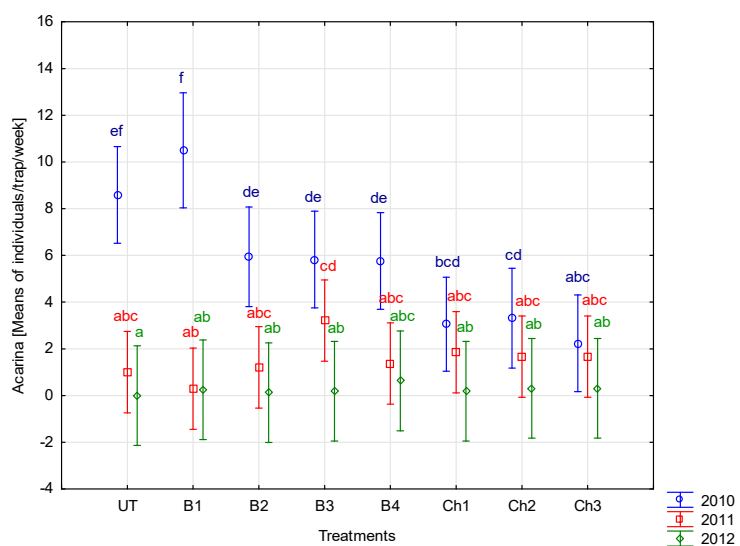

(b)

Figure 5. Number of trapped individuals of (a) Collembola and (b) Acarina in broad bean crop depending on the protection method used: Treatments are the same as in Table 1. Vertical bars denote 0.95 confidence intervals. Means followed by the same letters are not significantly different according to the LSD test $(p<0.05)$, factors: year $\times$ protection method.

Table 5. Results of the statistical analysis of the presence of Collembola and Acarina. SS-sum of squares, $d f$-degrees of freedom, MS—mean squares, F-Fisher-Snedecor's test, $p$-probability level.

\begin{tabular}{lccccc}
\hline \multicolumn{1}{c}{ Effects } & SS & $d f$ & MS & $\boldsymbol{F}$ & $p$ \\
\hline Year & 5165.697 & 2 & 2582.849 & 14.969 & 0.000 \\
Protection method & 1560.555 & 7 & 222.936 & 1.292 & 0.253 \\
Year $\times$ protection method & 2864.642 & 14 & 204.617 & 1.1859 & 0.283 \\
\hline \multicolumn{5}{c}{ Acarina } \\
\hline Year & 2090.394 & 2 & 1045.197 & 55.423 & 0.000 \\
Protection method & 243.435 & 7 & 34.776 & 1.844 & 0.077 \\
Year $\times$ protection method & 791.847 & 14 & 56.560 & 2.999 & 0.000 \\
\hline
\end{tabular}

A significant variation was found in the abundance of Acarina between the years that the research was conducted (Figure 5b). The interaction of the year and the protection method was also statistically proven (Table 5). In 2010, they were captured approximately 3.5 times more frequently than in 2011 and over 20 times more frequently than in 2012. The abundance of mites in 2010 was curbed by all chemical protection methods used. The maximum variant of chemical protection caused the strongest reduction in the abundance of soil mites. In the 2011 and 2012 seasons, the abundance of this group did not differ between treatments. Because of the differences found in 2010, the changes in the dynamics of Acarina were collated to discover if the decrease in the number of trapped individuals in the chemically protected sites (Ch2 and Ch3) was directly associated with the timing of insecticide application (Figure 6). The results indicate that indeed the highest decrease in the number of Acarina trapped compared with untreated site and with the application of nonchemical preparations was recorded between 15 June 2010 and 8 July 2010, i.e., immediately after the spraying with Fastac 100 EC preparation (15 June 2010). Later, the numbers of trapped Acarina were similar in all treatments. 


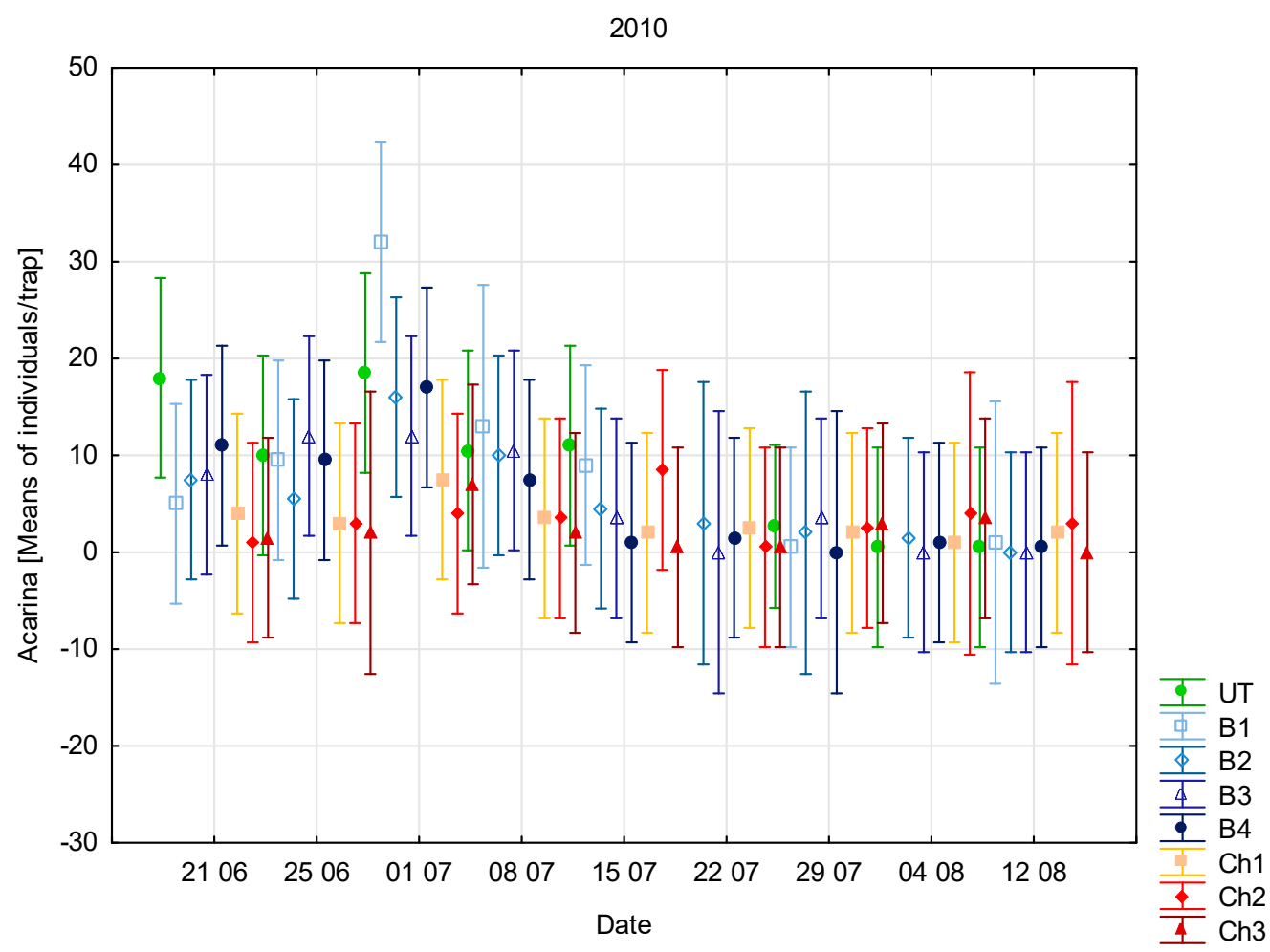

Figure 6. Trapping dynamics of Acarina in broad bean crop in the year 2010: Treatments are the same as in Table 1 . Vertical bars denote 0.95 confidence intervals.

\subsection{Selected Morphological Parameters of Broad Bean}

Broad bean plants treated with chemicals were significantly taller than untreated and biologically protected plants $(F=13.36, p<0.0001)$ but did not differ in the number of shoots produced $(F=1.36$, $p=0.22$ ) (Figure 7).

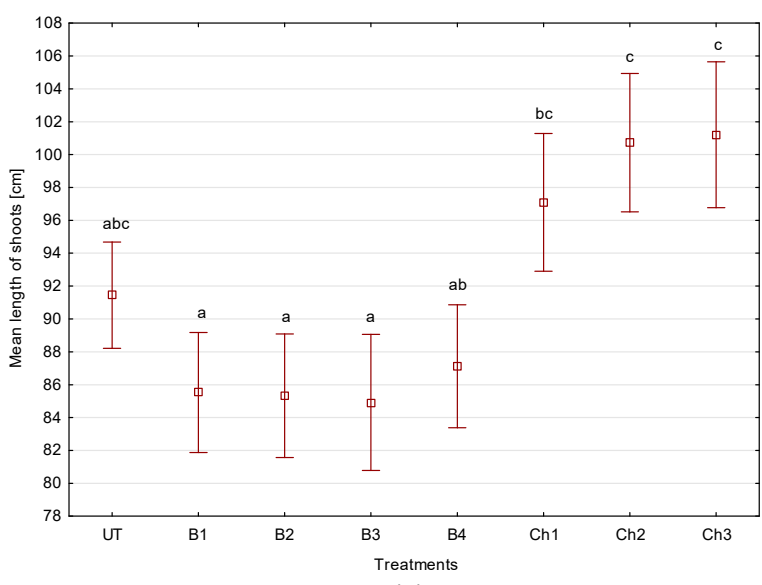

(a)

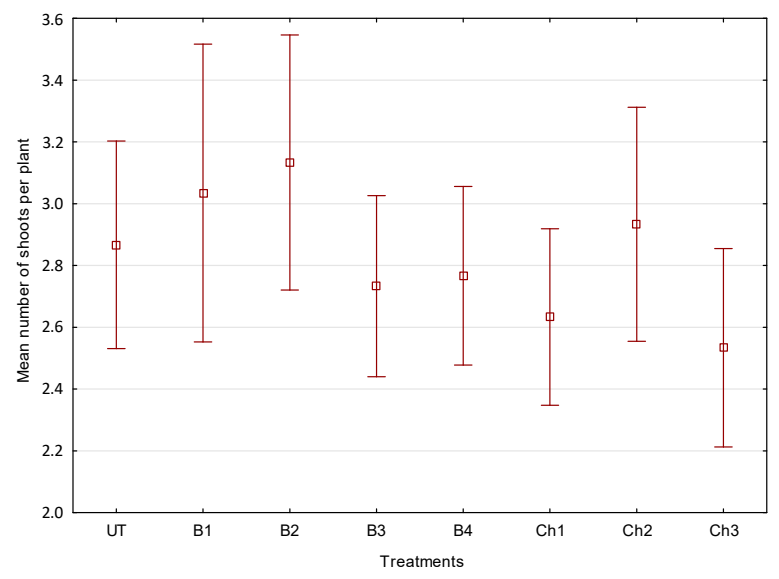

(b)

Figure 7. Length (a) and number of broad bean shoots (b) depending on the protection method used (mean in years 2010-2012): Treatments are the same as in Table 1. Vertical bars denote 0.95 confidence intervals. Means followed by the same letters are not significantly different according to the LSD test $(p$ $<0.05)$; in the case of number of shoots, means are not significantly different.

\section{Discussion}

The biological methods of broad bean protection using garlic pulp, grapefruit extract, and P. oligandrum have not made a significant impact on the occurrence of most of the studied groups 
of invertebrates. The differences in the intensity of protection (different number of sprayings) did not cause many differences in these parameters. In one of the seasons studied, compared with the chemical methods, biopreparations turned out to be safer for arachnids, particularly for Acarina. The available literature does not provide information on the effects on soil mites exerted by the abovementioned nonchemical preparations. Studies into the impact of pyrethroid insecticides (which include active substances used in our study) upon the occurrence of Acarina in pitfall traps have shown their significantly lower numbers in insecticide-treated plots than in untreated plots [20]. Vaj et al. [22] pointed out that Acarina (especially astigmatid mites) are vulnerable to a mixture of plant protection products (herbicides, fungicides, and insecticides), showing a significant decrease in number in the period of highest chemical load in vineyards. This has been reflected in the results of our study, although the intensity of protection (and thereby chemical load) in our experiment was much lower than in the vineyards. This indicated that soil mites seem to be group of arthropods which are very sensitive to plant protection products, both chemical and biological.

Despite not finding any significant effect of the method of protection on the occurrence of springtails, it is worth mentioning that, in the year of their most numerous appearance, Collembola displayed the highest abundance in the site, with a maximum number of chemical treatments. This result may be explained by the fact that chemical protection contributed to a higher degree of shading in the area, which in turn facilitated the penetration of the soil surface by Collembola. The application of chemical protection methods was more efficient in reducing the harmful impact of the black bean aphid foraging on broad bean than other methods used, thereby allowing the plants to grow to a bigger size. Many authors [6,29-32] emphasize the role of shading in enhancing the activity of epigeic and soil arthropods, including springtails. Another possible explanation may be that, among the taxa, springtails dominated families characterised by low vulnerability to plant protection products and there was an indirect effect of the absence of other taxa (e.g., those that could compete). Such an explanation was given by Vaj et al. [22], who also found that, after application of plant protection products (herbicides + fungicides + insecticides), the number of some Collembola families increased.

The results obtained therefore show no negative impact of either synthetic preparations or those produced from garlic and grapefruit extracts as well as with P. oligandrum on the abundance of carabids and rove beetles in general. Carabid beetles are included by some authors in the category of animals that show a negative correlation to the number of treatments with chemical plant protection products [21]. However, a growing body of research indicates a reduction in the negative impact of plant protection products on these animals, mainly due to a changed assortment and the improvement in chemical protection techniques $[35,36]$. It often happens that differences are no longer noted in the abundance of fauna in treated and untreated fields [35,36] or its abundance even rises [23,24]. Reported increases in pitfall trap captures of carabids after insecticide applications could be the result of hyperactivity or other indirect mechanisms: scavenging, reduced competition, hunger, impairment of hosts, or hormesis (positive biological responses on very low levels of harmful substances) [37]. Another possible explanation (similar to that in the case of Collembola) could be the indirect influence through plants—-bigger plants and thus greater shading — may create a better microclimate for epigeic fauna. Such an explanation was given by Hurej and Twardowski [6], who found the lowest number of carabids in a triticale monoculture, and as the share of lupine in the intercrop with wheat increased, the number of carabids caught increased too, being the largest in the yellow lupin monoculture.

The $\mathrm{H}^{\prime}$ index in our research was slightly elevated in biologically protected plots compared to untreated ones, but in chemically protected plots, the index was similar except for the treatment with fungicide carboxin only (Ch1). This may confirm the hypothesis about the significant influence of shading of the soil surface on the abundance of carabids. Broad bean as a plant is very vulnerable to pest damages, and chemical protection (by insecticide spraying) gives a very clear positive response in its growth $[10,11]$. The plants in the Ch1 treatment were smaller than that in the Ch2 and Ch3 treatments, which may partly explain the lower $\mathrm{H}^{\prime}$ value (worse conditions for more vulnerable species). Moreover, a possible negative effect of insecticides which were used only in $\mathrm{Ch} 2$ and $\mathrm{Ch} 3$ on carabids abundance 
could be leveled (masked) by the greater ground cover (and thus better conditions for fauna). Studies by Hummel et al. [5] prove that the degree of ground cover in a cultivated plot affects the abundance of most invertebrates. Smaller numbers of carabid beetles as well as a lower species diversity are usually correlated with a lesser vegetation cover $[6,38,39]$, which is partly supported by the results of this study, as in one research season (2011), the largest numbers of beetles were trapped in the sites subjected to chemical protection, where the degree of ground cover was the highest. Such an explanation was also proved by results obtained by Hurej and Twardowski [6].

Although we did not find any statistically proven influence of protection methods used on the total abundance of carabids, there were some significant differences in the response of individual carabid species. One species-A. dorsalis-responded with an increase in abundance as a result of chemical protection while two others-A. aenea and P. assimilis-preferred biologically protected plots. This may indicate that there is a difference in the vulnerability of these three species to plant protection products. A. dorsalis, in the research by Kromp [40], showed similar activity densities under two type of cultivation (biological and conventional), which means that it is not very sensitive to chemical plant protection, and this partly agrees with our results. Moreover, this author [40] found that both the total number of captured carabid beetles and the number of species were larger in biological system on potato fields than in conventional ones in two of the three years of research. Only one species-Pterostichus melanarius-was more commonly found in conventional fields. In our research, P. melanarius was also caught more often on chemically protected plots, although the differences were not statistically proven.

Rove beetles, just like carabid beetles, are a group of invertebrates that also react positively to increased ground cover with vegetation [41]. Altieri at al. [42] recorded a significantly larger number of Staphylinidae in weedy and clover plots than in clean cultivated plots. In our experiment, in one season (2012), rove beetles were caught most often in a chemically protected site with moderate intensity (Ch2).

Our results showed that ants preferred plots protected with nonchemicals (especially with P. oligandrum only). They were caught there more frequently than in non-protected plots. However, the increasing frequency of the use of garlic extract reduced their numbers. In the available literature, there is no information about the influence of such measures on the abundance of ants in field conditions. Garlic extract tested in laboratory conditions in a closed space (Petri dishes), along with 5 other botanical extracts, has shown one of the weakest negative effect on survival of the predatory ant Paratrechina sp. [43]. Reducing the occurrence of ants under the influence of garlic extract may also be associated with the limiting effect of this preparation on the occurrence of aphids (both groups of insects are positively correlated [44]). Ants are known to live in close relationship with aphids, and their role in this context is unfavorable (they protect aphids against their natural enemies) [45]. Our results indicate that the numerous presence of these insects on plots protected exclusively with P. oligandrum may result in an increase in the degree of infestation of plants by aphids.

\section{Conclusions}

- Nonchemical protection measures applied to broad bean, such as the use of products based on garlic and grapefruit extracts and a preparation containing Pythium oligandrum, did not significantly affect the overall abundance of fauna and the major groups of invertebrates, such as Arachnida (except for Acarina), Carabidae, Staphylinidae, and Collembola. These methods (especially P. oligandrum dressing), however, may favor the occurrence of Formicidae.

- In comparison to the protection of broad beans with chemical products (carboxin, mancozeb, deltamethrin, and alpha-cypermethrin), nonchemical methods seemed to be safer for mites-they limited their abundance to a lesser degree. However, more detailed research is needed to evaluate the individual taxa response.

- Nonchemical protection measures facilitated a slight increase in biodiversity of beetles from the carabid family. Some individual carabid species showed differing responses to applied protection 
methods: Amara aenea occurred only in nonchemically protected areas, Platynus assimilis tends to prefer broad bean protected solely with P. oligandrum, while Anchomenus dorsalis preferred plants protected with chemicals in a moderate way (seed treatment and three-time spraying). This may be the effect of the different shading of the soil surface as a result of the influence of protection measures on plant growth or different vulnerability of species to preparations as well as indirect reaction to the occurrence of other taxa.

- Studied biological substances were demonstrated to be largely safe for nontarget organisms. Therefore, their use in plant-protection practice should be further recommended. However, significant impact of those substances was found on certain invertebrates (e.g., Acarina and Formicidae), which provides the basis for further research toward the accurate identification of affected species and an explanation of mechanisms behind such affection. In case of species belonging to the Carabidae family, in which a significant change in occurrence was observed, it is recommended to study their vulnerability to the tested active substances under laboratory conditions. Such studies could explain the causes of the observed phenomenon.

Supplementary Materials: The following are available online at http://www.mdpi.com/2073-4395/10/2/211/s1, Table S1: The number and species composition of Carabidae in broad bean crop depending on the protection method used. Treatments as in Table 1, Table S2: Results of the statistical analysis of the presence of other Carabidae species.

Author Contributions: Conceptualization, J.G. and E.B.; methodology, J.G.; software, J.G.; validation, J.G., E.B. and K.G.-K.; formal analysis, J.G.; investigation, J.G., E.B. and K.G.-K.; writing-original draft preparation, J.G.; writing-review and editing, J.G.; visualization, J.G.; supervision, E.B.; project administration, E.B. All authors have read and agree to the published version of the manuscript.

Funding: Scientific publication financed from the funds for science in 2009-2013 as a research project (NN 310038 438) and by the Ministry of Science and Higher Education of the Republic of Poland.

Conflicts of Interest: The authors declare no conflict of interest. The funders had no role in the design of the study; in the collection, analyses, or interpretation of data; in the writing of the manuscript; or in the decision to publish the results.

\section{References}

1. Hikal, W.M.; Baeshen, R.S.; Said-Al. Ahl, H.A.H. Botanical insecticide as simple extractives for pest control. Cogent Biol. 2017, 3, 1404274. [CrossRef]

2. Gahukar, R.T. Plant-derived products in crop protection: Effects of various application methods on pests and diseases. Phytoparasitica 2016, 44, 379-391. [CrossRef]

3. Kowalska, J. Organically grown Brassica napus-use of border strips and Trichoderma. Acta Agric. Scand. B Soil Plant Sci. 2014, 64, 529-536. [CrossRef]

4. Gahukar, R.T. Potential and Utilization of Plant Products in Pest Control. In Integrated Pest Management, Current Concepts and Ecological Perspective; Elsevier: San Diego, CA, USA; London, UK; Waltham, MA, USA, 2014; pp. 125-139. [CrossRef]

5. Hummel, R.L.; Walgenbach, J.F.; Hoyt, G.D.; Kennedy, G.G. Effects of vegetable production system on epigeal arthropod populations. Agric. Ecosyst. Environ. 2002, 93, 177-188. [CrossRef]

6. Hurej, M.; Twardowski, J.P. The influence of yellow lupine intercropped with spring triticale on predatory carabid beetles (Coleoptera:Carabidae). Eur. J. Entomol. 2006, 103, 259-261. [CrossRef]

7. Prasifka, J.R.; Schmidt, N.P.; Kohler, K.A.; O’Neal, M.E.; Hellmich, R.L.; Singer, J.W. Effects of living mulches on predator abundance and sentinel prey in a corn-soybean-forage rotation. Environ. Entomol. 2006, 35, 1423-1431. [CrossRef]

8. Jezierska-Tys, S.; Rutkowska, A. Soil response to chemicals used in a field experiment. Int. Agrophys. 2013, 27, 151-158. [CrossRef]

9. Wenda-Piesik, A.; Piesik, D. Efficacy of garlic extract. In the control of Sitona spp. on pea. Progr. Plant Prot. 2009, 49, 2038-2043. (In Polish, English abstract).

10. Gospodarek, J.; Boligłowa, E.; Glen, K. Comparison of the non-chemical and chemical method for broad bean protection against Sitona spp. Prog. Plant Prot./Post. Ochr. Roślin 2012, 52, 26-30. (In Polish, English abstract). 
11. Gospodarek, J.; Gleń, K.; Boligłowa, E. Effect of non-chemical preparations application in broad bean protection against harmfulness of broad bean seed beetle (Bruchus rufimanus Boh.) and seed yield. J. Res. Appl. Agric. Engin. 2012, 57, 124-128.

12. Akyazi, R.; Soysal, M.; Altunc, E.Y.; Lisle, A.; Hassan, E.; Akyol, D. Acaricidal and sublethal effects of tobacco leaf and garlic bulb extract and soft soap on Tetranychus urticae Koch. (Acari: Trombidiformes: Tetranychidae). Syst. Appl. Acarol. UK 2018, 23, 2054-2069. [CrossRef]

13. Ismail, M.S.M.; Soliman, M.F.M.; Abo-Ghalia, A.H.; Ghallab, M.M.A. The acaricidal activity of some essential and fixed oils against the two-spotted spider mite in relation to different temperatures. Int. J. Pest Manag. 2015, 61, 121-125. [CrossRef]

14. Geng, S.; Chen, H.; Zhang, J.; Tu, H. Bioactivity of Garlic-Straw Extracts Against the Spider Mites, Tetranychus urticae and T-viennensis. J. Agric. Urban Entomol. 2014, 30, 38-48. [CrossRef]

15. Rosa Pino-Otin, M.; Val, J.; Ballestero, D.; Navarro, E.; Sanchez, E.; Gonzalez-Coloma, A.; Mainar, A.M. Ecotoxicity of a new biopesticide produced by Lavandula luisieri on non-target soil organisms from different trophic levels. Sci. Total Environ. 2019, 671, 83-93. [CrossRef] [PubMed]

16. Rosa Pino-Otin, M.; Val, J.; Ballestero, D.; Navarro, E.; Sanchez, E.; Mainar, A.M. Impact of Artemisia absinthium hydrolate extracts with nematicidal activity on non-target soil organisms of different trophic levels. Ecotoxicol. Environ. Saf. 2019, 180, 565-574. [CrossRef] [PubMed]

17. Alves, P.R.L.; Cardoso, E.J.B.N.; Martines, A.M.; Sousa, J.P.; Pasini, A. Seed dressing pesticides on springtails in two ecotoxicological laboratory tests. Ecotoxicol. Environ. Saf. 2014, 105, 65-71. [CrossRef]

18. Cloyd, R.A.; Herrick, N.J. Effects of Pesticides on the Survival of Rove Beetle (Coleoptera: Staphylinidae) and Insidious Flower Bug (Hemiptera: Anthocoridae) Adults. J. Econ. Entomol. 2018, 111, 78-88. [CrossRef]

19. Frampton, G.K. RecoFvery responses of soil surface Collembola after spatial and temporal changes in long-term regimes of pesticide use. Pedobiologia 2000, 44, 489-501. [CrossRef]

20. Huuselaveistola, E.; Kurppa, S.; Pihlava, J.M. Effects of fenvalerate and permethrin on soil arthropods and on residues in and decomposition of barley straw. Agric. Food Sci. 1994, 3, 213-223. [CrossRef]

21. Kosewska, A. Effect of plant protection treatments on the occurrence of ground beetles (Col. Carabidae) in selected plant plantations. Progr. Plant Prot. 2012, 52, 529-534, (In Polish, English abstract).

22. Vaj, C.; Van Gestel, C.A.M.; Vighi, M. Year-round behaviour of soil microarthropod communities under plant protection product application. Ecotoxicology 2014, 23, 898-913. [CrossRef] [PubMed]

23. Chiverton, P.A. Pitfall-trap catches of the carabid beetle Pterostichus melanarius, in relation to gut contents and prey densities, in insecticide treated and untreated spring barley. Entomol. Exp. Appl. 1984, 36, 23-30. [CrossRef]

24. Bel'skaya, E.A.; Zinov'ev, E.V.; Kozyrev, M.A. Carabids in a spring wheat agrocenosis to the south of Sverdlovsk oblast and the effect of insecticide treatment on their populations. Russ. J. Ecol. 2002, 33, 38-44. [CrossRef]

25. Seidenglanz, M.; Huňady, I.; Poslušna, J.; Loes, A.K. Influence of intercropping with spring cereals on the occurrence of pea aphids (Acyrthosiphon pisum Harris, 1776) and their natural enemies in field pea (Pisum sativum L.). Plant Protect. Sci. 2011, 47, 25-36. [CrossRef]

26. Holland, J.M.; Smith, S. Sampling epigeal arthropods: An evaluation of fenced pitfall traps using mark-release-recapture and comparisons to unfenced pitfall traps in arable crops. Entomol. Exp. Appl. 1999, 91, 347-357. [CrossRef]

27. Hurka, K. Carabidae of the Czech and Slovak Republics; Kabourek: Zlin, Czech Republic, 1996; p. 565.

28. Querner, P.; Bruckner, A. Combining pitfall traps and soil samples to collect Collembola for site scale biodiversity assessments. Appl. Soil Ecol. 2010, 45, 293-297. [CrossRef]

29. Gonzalez, E.; Salvo, A.; Valladares, G. Natural vegetation cover in the landscape and edge effects: Differential responses of insect orders in a fragmented forest. Insect Sci. 2017, 24, 891-901. [CrossRef]

30. Wasley, J.; Mooney, T.J.; King, C.K. Soil invertebrate community change over fuel-contaminated sites on a subantarctic island: An ecological field-based line of evidence for site risk assessment. Integr. Environ. Asses. 2016, 12, 306-314. [CrossRef]

31. Gospodarek, J.; Petryszak, P.; Kołoczek, H. The effect of the bioremediation of soil contaminated with petroleum derivatives on the occurrence of epigeic and edaphic fauna. Bioremed. J. 2016, 20,38-53. [CrossRef] 
32. Rusin, M.; Gospodarek, J. The occurrence of springtails (Collembola) and spiders (Araneae) as an effectiveness indicator of bioremediation of soil contaminated by petroleum-derived substances. Int. J. Environ. Res. 2016, 10, 449-458.

33. Shannon, C.E.; Wiener, W. The Mathematical Theory of Communication; University of Illinois: Urbanna, VI, USA, 1949.

34. Santos, S.; Cabanas, J.E.; Pereira, J.A. Abundance and diversity of soil arthropods in olive grove ecosystem (Portugal): Effect of pitfall trap type. Eur. J. Soil Biol. 2007, 43, 77-83. [CrossRef]

35. Pruszyński, S. Plant protection in different cropping systems and biological diversity. Progr. Plant Prot. 2009, 49, 1092-1101, (In Polish, English abstract).

36. Kos, T.; Bažok, R.; Drmić, Z.; Graša, Ž. Ground beetles (Coleoptera: Carabidae) in sugar beet fields as the base for conservation biological control. Insect Pathogens and Entomoparasitic Nematodes. Biological Control its unique role in integrated and organic production. IOBC WPRS Bull. 2013, 90, 353-357.

37. Prasifka, J.R.; Lopez, M.D.; Hellmich, R.L.; Prasifka, P.L. Effects of insecticide exposure on movement and population size estimates of predatory ground beetles (Coleoptera: Carabidae). Pest Manag. Sci. 2008, 64, 30-36. [CrossRef] [PubMed]

38. Eyre, M.D.; Labanowska-Bury, D.; Avayanos, J.G.; White, R.; Leifert, C. Ground beetles (Coleoptera, Carabidae) in an intensively managed vegetable crop landscape in eastern England. Agric. Ecosyst. Environ. 2009, 131, 340-346. [CrossRef]

39. Navntoft, S.; Esbjerg, P.; Riedel, W. Effects of reduced pesticide dosages on carabids (Coleoptera:Carabidae) in winter wheat. Agric. Forest Entomol. 2006, 8, 57-62. [CrossRef]

40. Kromp, B. Carabid beetles (Coleoptera, Carabidae) as bioindicators in biological and conventional farming in Austrian potato fields. Biol. Fertil. Soils 1990, 9, 182-187. [CrossRef]

41. Gruss, I.; Twardowski, J.P.; Hurej, M.; Kozak, M. Effect of intercropping narrow-leafed lupin with spring triticale on the abundance and diversity of rove beetles. Biotechnol. Agron. Soc. 2018, 22, 220-229.

42. Altieri, M.A.; Wilson, R.C.; Schmidt, L.L. The effects of living mulches and weed cover on the dynamics of foliage- and soil-arthropod communities in three crop systems. Crop Prot. 1985, 4, 201-213. [CrossRef]

43. Silva, R.S.; Tomaz, A.C.; Lopes, M.C.; Martins, J.C.; Xavier, V.M.; Picanco, M.C. Toxicity of botanical insecticides on Diaphania hyalinata, their selectivity for the predatory ant Paratrechina sp., and their potential phytotoxicity on pumpkin. Int. J. Pest Manag. 2016, 62, 95-104. [CrossRef]

44. Gospodarek, J. Occurrence of Black Bean Aphid (Aphis Fabae Scop.) and Its Natural Predators on Broad Bean Under the Conditions of Soil Pollution with Heavy Metals. Zesz Nauk UR W Krakowie 2012, 480, 207. (In Polish, English abstract).

45. Powell, B.E.; Silverman, J. Impact of Linepithema humile and Tapinoma sessile (Hymenoptera: Formicidae) on three natural enemies of Aphis gossypii (Hemiptera: Aphididae). Biol. Control 2010, 54, 285-291. [CrossRef] 